\title{
The effectiveness Of Problem Solving and Problem Posing Method in Geographic Learning Viewed from Locus of Control High Schol Students in Sleman District Special Region of Yogyakarta
}

\author{
Fahririn Ajid', Muhsinatun Siasah Masruri² \\ Yogyakarta State University, Dept. of Magister geography Education ${ }^{1}$ Yogyakarta State University, \\ Dept. of Magister geography Education ${ }^{2}$.
}

fahririn0360pasca.2018@student.uny.ac.id¹muhsinatun_siasah@uny.ac.id

\begin{abstract}
This study aims to knowing; 1) differences in the effectiveness of geography learning outcomes between high school students studying with the Problem-Solving method and those learning with the Problem Posing method, 2) differences in the effectiveness of learning outcomes between groups of students with the Locus of control Introvert obtained through learning with the Problem Solving and Problem Posing methods in high school, 3) differences in the effectiveness of learning outcomes between groups of students with extrovert Locus of control obtained through learning with the Problem Solving and Problem Posing methods in high school. The results showed There is a difference in the effectiveness of learning outcomes between Problem Posing and Problem Solving learning methods to improve geography learning outcomes, There is no difference in the effectiveness of geography learning outcomes between students who apply the Problem Posing and Problem Solving methods to the Introverted LoC group. There is a difference in the effectiveness of geography learning outcomes between students who apply the Problem Posing and Problem Solving methods to the Extrovert LoC group.
\end{abstract}

Keywords: Problem solving, problem posing, locus of control, learning outcomes

\section{Introduction}

Concerning the National Education System states that "Education is a conscious and planned effort to create an atmosphere of learning and learning process so that students actively develop their potential to have spiritual, religious, self-control, personality, intelligence, noble character, and skills that are it needs itself, the people, the Nation and the State [1]. In the current era of globalization, all forms of improvement in the field of education continue to be carried out to achieve better learning goals in the present and the future. Learning activities that can be done by applying various innovations in the learning process by current technological developments and knowledge. One form of the learning activity that is intended is the existence of a learning process, which requires skills and thinking abilities so that there are interactions between cognitive, affective, and psychomotor aspects of students in constructing knowledge.

Components attached to the educational process are "curriculum-teacher-students" that are interrelated. Based on this statement, one of the roles of the teacher is as a designer, actor, and evaluator of the learning outcomes that guide learning activities in the classroom [2]. In this case, the achievement of learning objectives is strongly influenced by student learning 
activities carried out jointly by the teacher. States that one of the principles of learning held is "fun" [3]. Therefore, the principle of "fun" that does not cause boredom in students, can be realized through the use of learning models, media, and learning resources that are relevant, and able to arouse student learning motivation. This is done so that students in learning not sleepy, so it is easy to understand the material delivered by the teacher, and learning outcomes can reach the minimum learning completeness criteria (KBM).

Based on observations made at Gama High School and in Colombo High School, Sleman Regency, two schools have student input and school facilities that are classified as good, have teachers or educators with appropriate qualifications. Both of these schools are Private Schools with Accreditation A, but in reality, there are still problems in the learning process, especially in learning geography. Thus with these problems, an example is needed for the application of models or learning methods that can be used by teachers to achieve learning objectives optimally. Learning methods that can be used include Problem Solving and Problem Posing. Problem Solving and Problem Posing learning methods are problem-based learning methods.

Even this cannot be separated from the characteristics of students, some like to follow learning, and some are not. revealed that thinking and acting can certainly not always be the same between one individual and another individual, as well as the personality characteristics of students also differ in the following learning in class [4]. That cannot be ignored in the learning process. Characteristics of students in one class there are various kinds of personality differences. There are two types of student characteristics, namely introverted and extroverted groups. states that a person is said to tend extroverted Locus of Control if the individual has the belief that whatever happens to them is influenced by outside forces such as luck or opportunity [5].

Based on the description, the researcher intends to research the Effectiveness of Problem Solving and Problem Posing Methods in Geography Learning in terms of the Locus of Contol Students in Sleman Regency High Schools, Special Region of Yogyakarta. The purpose of this study is to look at the effectiveness of student learning in geographic material, the difference in the effectiveness of students' Locus of control in both methods.

\section{Methods}

The method of research in this study consists of the types of research, population, and research samples which can be explained as follows:

\subsection{Type of Research}

This research is a quantitative study using a quasi-experimental approach (quasiexperimental). Namely experimental research that not all variables are controlled. Enforcement in this experimental research is learning by applying the Problem Solving and Problem Posing methods in geography learning in high school students of Sleman Yogyakarta Regency. This study involved two classes of students who were subjected to the study. The first group was treated with the Problem Posing learning method and the second group was given learning by the Problem Solving method. The research design used in this study is a $2 \times 2$ factorial design used to determine the effectiveness of two independent variables on the dependent variable. 


\subsection{Population and Research Samples}

The population in this study is all the objects studied in this study, namely high schools in Sleman, Yogyakarta. The sample in this study as part of the population that will be used as an object and is considered to represent the existing population. The sample in this study were 57 students consisting of 32 students in the first experimental group using the Problem Posing learning method, and 25 students in the second experimental group using the Problem Solving learning method.

\subsection{Description of Learning Outcomes}

This research was conducted in class XI IPS in Sleman Yogyakarta High School which is an A accredited private school with a variety of different students. This type of research is experimental research, namely in the first experimental class with 32 students and with 25 students as the second experimental class. The results of the research on student learning outcomes.

The conclusion of the discussion, then based on the results of the average value (mean) before the provision of treatment (Pre-test) and after being given treatment (Post-test) showed an increase in the results of students' parallel level with the acquisition of the Pre-test mean value of 42.50 and the value of Post-test mean of 87.50. Likewise, with these results, the nGain calculation of the Problem Posing learning method is effective in improving student learning outcomes by obtaining an N-Gain score of 0.4550 and is included in the medium effectiveness category. Geography student learning outcomes for Pre-test and Post-test in the student who groups applying the Problem-Solving learning method at High School. which can be addressed in the following diagram.

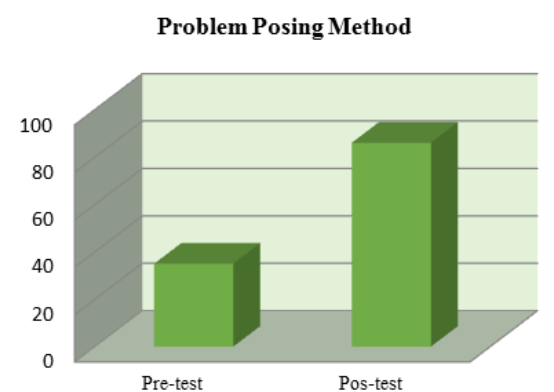

Fig.1. Average Diagram of PP Group Geography Learning Outcomes

\section{Problem Solving Method}

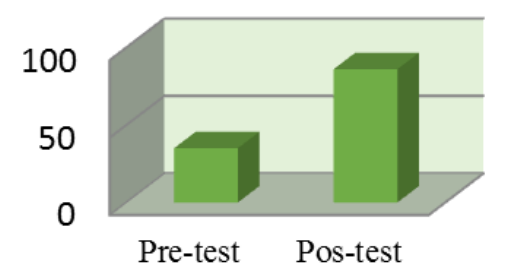

Fig.2. Average Study Results Geography PS Group 
Based on this discussion, it can be concluded that the results of the average value (mean) before the treatment (Pre-test) and after the treatment (Post-test) with the Problem-Solving learning method there is an increase in student learning outcomes by obtaining the value of the mean Pre-test of 35.80, and the mean value for Post-test of 86.40, so that the calculation of the results of the N-Gain Problem-Solving learning method is effective in improving student learning outcomes with the acquisition of 0.3680 , which is included in the medium effectiveness category. Furthermore, it can be shown the results of the Locus of Control questionnaire test on groups of students with the treatment of the Problem Posing learning method at the High School, Sleman, as follows:

Table 1. Description of Student Locus of Control Data Groups Problem Posing Method.

\begin{tabular}{ccc}
\hline & \multicolumn{2}{c}{ Problem Posing Method } \\
\hline & Ekstrovert & Introvert \\
Frequency & 18 & 14 \\
Percent & 56.3 & 43.8 \\
N-Gain & 0.4500 & 0.3929 \\
\hline
\end{tabular}

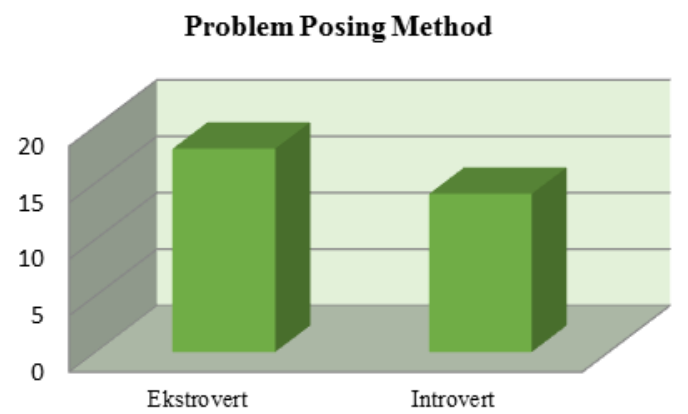

Fig.3. Percentage of Locus of Control of PP Group Students.

Thus based on the explanation, it can be concluded that the students who were given the problem-posing method treatment at the High School Sleman, as a whole, there were a majority of students who had 18 extroverted personalities with a percentage gain of $56.3 \%$ and 14 other students had an introverted personality with a percentage gain by $43.5 \%$. Calculation of the results of the N-Gain group by treatment of the Problem Posing learning method of the Esktrovert students get grades that are included in the medium category and students with Introverted personality $\mathrm{N}$-Gain results obtained fall into the medium category. Furthermore, the Locus of Control questionnaire test results on the group of students with the treatment of the Problem Solving method at Sleman High School, as follows:

Table 2. Group Locus of Control Data Description Problem Solving Method

\begin{tabular}{lcc} 
& \multicolumn{2}{c}{ Problem Solving Method } \\
\cline { 2 - 3 } & Ekstrovert & Introvert \\
\hline Frequency & 16 & 9 \\
Percent & 63.6 & 35.5 \\
N-Gain & 0.3625 & 0.3500 \\
\hline
\end{tabular}




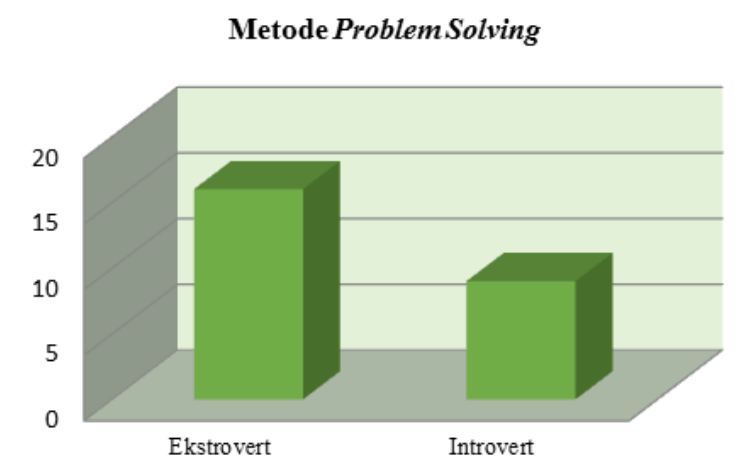

Fig.4. Percentage of Locus of Control of PS Group Students.

Thus it can be concluded that students in the class who were treated with the Problem Solving method at Sleman High School, the majority of students were extroverted, with a total of 16 students with a percentage of $63.6 \%$ and 9 students with a percentage of $35.5 \%$. Thus the calculation of the value of $\mathrm{N}$-Gain in groups of students treated the method of learning Problem Solving Introvert and Extrovert personality included in the medium category.

\section{Results And Discussion}

Table 3. Results of Two Way Anova Analysis of Problem Solving and Problem Posing Methods

\begin{tabular}{ccccccc}
\multicolumn{7}{c}{ Against Learning Outcomes } \\
\hline Method & $\begin{array}{c}\text { Average } \\
\text { Pre-test }\end{array}$ & $\begin{array}{c}\text { Sum of Square } \\
\text { Post-test }\end{array}$ & Df & $\begin{array}{c}\text { Mean } \\
\text { Square }\end{array}$ & F & Sig \\
\hline PP & 42.50 & 87.50 & 1 & 565.31 & 9.024 & 0.002 \\
PS & 35.80 & 86.40 & & & & \\
\hline
\end{tabular}

The data in table 3, it can be seen that the calculated $\mathrm{F}$ value $>\mathrm{F}$ table is $9,204>4.01$, which shows that $\mathrm{HO}$ is rejected and $\mathrm{Ha}$ is accepted in the sense that there is a difference in effectiveness between the learning methods of Problem Solving and Problem Posing in improving student learning outcomes. The value of Probability between Problem Solving learning methods and Problem Posing methods with learning outcomes is $0.002<0.05$, thus it can be concluded that there is a difference in effectiveness between the Problem-Solving learning method and the Problem Posing method in improving student learning outcomes.

Table 4. Introverted Group T-Test Analysis Results

\begin{tabular}{cccccc}
\hline LoCEkstrovert & Frequence & df & Mean Difference & T & Sig \\
\hline PP & 14 & 1 & 476.19 & 0.182 & 0.856 \\
PS & 9 & & & & \\
\hline
\end{tabular}

In table 4 , it shows that the calculated $\mathrm{T}$ value $<\mathrm{T}$ table is $0.182<4.01$, while for the significance value of $0.856>0.05$, which proves that $\mathrm{H} 0$ is accepted and a is rejected in the sense that there is no difference in the effectiveness of geography learning outcomes between students who applied the Problem Problem method Solving and Problem Posing in the Locus of Control Introvert group in Sleman Yogyakarta High School. 
Table 5. Analysis Results of the Extroverted Group T-test

\begin{tabular}{cccccc}
\hline LoCEkstrovert & Frequence & Df & Mean Difference & T & Sig \\
\hline PP & 18 & 1 & 463.336 & 4.560 & 0.001 \\
PS & 16 & & & & \\
\hline
\end{tabular}

In table 5, the results of the data show that the calculated $\mathrm{T}$ value $>\mathrm{T}$ table is $4,560>4.01$, while the significance value is $0.001<0.05$, which proves that $\mathrm{H} 0$ is rejected and $\mathrm{Ha}$ is accepted with the meaning that there are differences in the effectiveness of geography learning outcomes between students who applied Problem Solving and Problem Posing methods in the Extrovert Locus of Control group in Sleman Yogyakarta High School.

\section{Conclussion}

The results showed that the application of the Problem Posing and Problem Solving Learning methods in the Locus of Control Extrovert and Introvert groups could improve learning outcomes. There is a difference in effectiveness between the Problem Posing learning method and the Problem Solving learning method. Student learning. There is no difference in the effectiveness of geography learning outcomes between students who applied the ProblemSolving and Problem-Posing methods in the Locus of Control Introvert group in Sleman Yogyakarta High School, with a tcount $<$ ttable value of $0.182<4.01$, while for a significance value of $0.856>0.05$, which prove that $\mathrm{H} 0$ was accepted and $\mathrm{Ha}$ was rejected. There is a difference in the effectiveness of geography learning outcomes between students who applied the Problem-Solving and Problem-Posing methods in the Extrovert Locus of Control group in Sleman Yogyakarta High School, with a tcount $>$ ttable of $4.560>4.01$ with an average value of 88.21 smaller than using the Problem Posing method is 89.7 and is at the 0.05 significance level.

\section{References}

[1] Undang-undang Republik Indonesia Nomor 20 Tahun 2003 Tentang Sistem Pendidikan Nasional.

[2] Amri, F.: Pengembangan dan Model Pembelajaran Dalam Kurikulum 2013. Prestasi Pustaka. Jakarta, (2013).

[3] Sanjaya, Wina.: Strategi Pembelajaran Berorientasi Standar Proses Pendidikan. Jakarta: Kencana, (2011).

[4] Irawati, R.,K.: Pengaruh Model Problem Solving dan Problem Posing serta kemampuan awal terhadap hasil belajar siswa. Jurnal Pendidikan Sains, 2 (4), 184-192, (2015).

[5] Robbins, S.: Perilaku Organisasi. Terjemahan: Benyamin Molan. New Jersey Prentice Hall, inc, (2007).

[6] Maulina, R., Wahyuni, A., \& Halim, A.: The Application of Problem Posing Learning Model to Improve Physics Learning Outcomes on Sound Wave Material. Vol 2.1, (2020).

[7] Ozkurt, T., \& Guven, B.: Evaluating Students' Beliefs in Problem Solving Process: A Case Study, 12(2), 411-429, (2016). 
[8] Suna, C., Valerie, J., Angel, S., Jade, S., Nicholas, Y., \& DMello, S. D.: Towards a generalized competency model of collaborative problem solving. Computer \& Education. Volume 143, ( 2020).

[9] Wainwright, W., A., Laan, N., Wen, D., \& Gašević, D.: Exploring student information problem solving behaviour using fine-grained concept map and search tool data. Computers \& Education, Volume 145, (2020).

[10] Ye, X., D., Chang, Y., H., \& Lai, C., L.: An interactive problem-posing guiding approach to bridging and facilitating pre- and in-class learning for flipped classrooms. Interactive Learning Environments, (2018). 